\title{
Effect of Per Os Iron Lactate Supplement on Development of Haematological Profile of Piglets in the Early Postnatal Period
}

\author{
M. SVOBODA ${ }^{1}$, J. BOUDA ${ }^{2}$, J. DRÁBEK ${ }^{1}$, J. DOUBEK $^{1}$ \\ ${ }^{1}$ University of Veterinary and Pharmaceutical Sciences, Faculty of Veterinary Medicine, Brno, Czech Republic \\ ${ }^{2}$ Facultad de Medicina Veterinaria y Zootecnica, Universidad Nacional Autónoma de México
}

Received June 2, 2004

Accepted October 26, 2004

\section{Abstract}

Svoboda M., J. Bouda, J. Drábek, J. Doubek: Effect of Per Os Iron Lactate Supplement on Development of Haematological Profile of Piglets in the Early Postnatal Period. Acta Vet. Brno 2004, 73: 431-436.

The objective of this study was to determine the effect of oral administration of Fe lactate (LaFe) on the postnatal development of haematological indices of piglets. The first group of 39 piglets received an oral dose of $134 \mathrm{mg} /$ piglet $\mathrm{Fe}^{2+}$ in the form of lactate paste $(\mathrm{LaFe})$ on day 3 of life. The administration was repeated on day 10 after birth. A classical treatment, e.g. single i.m. administration of $200 \mathrm{mg} \mathrm{Fe}^{3+} /$ piglet in the form of dextran (DeFe) was carried out in the second group of 30 piglets on day 3 after birth. A group of 20 untreated piglets served as anaemic control. At the end of week 1, highest values of $\mathrm{Hb}, \mathrm{PCV}$ and $\mathrm{MCH}$ were found in the lactate group $(p<0.01)$. At the age of 14 days, significantly higher plasma concentration of Fe and higher RBC were found in piglets supplemented with lactate paste $(p<0.01)$. On day 28 of life significantly higher values of most haematological indices were recorded in the group with i.m. administration of DeFe $(p<0.01)$. The two groups did not differ in their somatic development. In control piglets anaemia occurred on day 7 after birth.

Although the administration of lactate $\mathrm{Fe}$ on days 3 and 10 of life positively influenced haematological values in the first three weeks of piglet life, in the fourth week symptoms of depletion of Fe reserves occurred.

Anaemia of piglets, iron, blood picture, piglet growth

Sideropenic anaemia of suckling piglets is a serious disease that should be prevented in time by iron supplementation. An administration of $\mathrm{Fe}^{3+}$ in the form of dextran is the most frequently used method. Such supplementation is usually recommended to carry out on day 3 of piglet life (Carls s on 1974; Y u et al. 2002). However, parenteral administration of iron to piglets after birth is not always free of health risks. Older papers published by Süvege s and Glávits (1976), A vram et al. (1982), Kolb and Hoffmann (1989) reported potential toxic effects of sudden Fe influx into the organism. According to Kolb et al. (1992), Morris et al. (1995) and Lehman (2001) a negative impact of parenterally administered $\mathrm{Fe}^{3+}$ causes the inhibition of macrophages, weakening their phagocytic abilities. Other authors, e.g. Heinritzi et al. (1997), claimed that a high supply of iron contributed to development of bacteraemia. Holmgren (1996) reported a more frequent occurrence of polyarthritis in this context. Fe pastes for oral administration were already developed and used in the past (Schmitz and Müller 1971) as a solution to frequent complications associated with parenteral supplementation of $\mathrm{Fe}$. As the absorption of $\mathrm{Fe}^{2+}$ is much better than that of $\mathrm{Fe}^{3+}$ (Dietzfelbinger 1987), only preparations containing bivalent iron are used for paste production. Experience in the use of ferrous sulphate (Schmitz and Müller 1971), Fe fumarate (S voboda and Drábek 2002) and Fe lactate (Kotrbáček 2001) was described. Lactate is a compound with sufficiently high concentration of $\mathrm{Fe}^{2+}$ ions necessary for oral administration. The bond of Fe to the organic acid commonly present in the organism is also

Address for correspondence:

MVDr. Martin Svoboda, Ph. D

University of Veterinary and Pharmaceutical Sciences

Palackého 1-3, 61242 Brno

Phone: +420 541562433

Czech Republic 
an advantage. Good absorbability of lactate Fe was proved under experimental conditions in one-day-old piglets (Kotrbáček 2001). But no data on the practical administration of lactate paste for prevention of anaemia in piglets are available for the time being. The objective of the present study was to acquire such data in a piglet operation.

\section{Materials and Methods}

Experiments were conducted in a commercial farrowing house. Sows were transferred into farrowing pens a fortnight before parturition where they stayed until weaning, i.e. until day 28 of piglet life. Nine litters with the total number of 89 piglets were included in the experiment. Experimental piglets were divided into 3 groups. On day 3 after birth the first group of 39 piglets received a per os paste containing $134 \mathrm{mg} \mathrm{Fe} /$ piglet in the form of lactate $(\mathrm{LaFe})$. Paste administration was repeated in these piglets on day 10.

On day 3 after birth a classical i.m. administration of $200 \mathrm{mg} \mathrm{Fe}{ }^{3+} /$ piglet in the form of dextran was carried out in the second group of 30 piglets. The third group of 20 piglets did not receive any iron in the first three weeks of life. On day 21 they were given $200 \mathrm{mg} \mathrm{Fe}{ }^{3+} /$ piglet by i.m. injection. From day 7 all piglets had access to drinking water and to a feed mixture for piglets that contained $248 \mathrm{mg} \mathrm{Fe} / \mathrm{kg}$. This feed was also administered in the first week after weaning, i.e. until day 35 of piglet life. Blood samples from the vena cava cranialis were taken on days $7,14,21,28$ and 35 in all groups of piglets. The following indicators were determined in the blood samples: haemoglobin concentration (Hb), packed cell volume (PCV), red blood count (RBC) and plasma iron concentration. Other haematological parameters were calculated from the basic data: mean corpuscular volume (MCV), mean corpuscular haemoglobin concentration (MCHC) and mean corpuscular haemoglobin (MCH). Piglets were weighed after birth and on days 7, 14,21,28, and 35 of their life. Student's $t$-test was used for statistical processing of all data by the programme Microsoft Excel 7.0.

\section{Results}

The results are presented as mean values and standard deviations of each index in Fig. 1-8. Group 1 = lactate group, Group $2=$ dextran group, Group $3=$ anaemic group. Values with $* p<0.05$ and $* * p<0.01$ express significant difference between dextran group and the two other groups. At the end of the first week of life the highest values of $\mathrm{Hb}, \mathrm{PCV}$ and $\mathrm{MCH}$ were measured in the piglets of lactate group (Figs. 1, 2, 5). They were significantly higher than the values determined in the piglets of dextran group, and especially than in control piglets without supplementation. As expected, in this so called anaemic group there was a further decrease in all examined values in the subsequent two weeks of experiment (Figs. 1-6). In 14-days-old piglets a significant difference between the two groups with different supplementation was recorded in the plasma Fe concentration. The piglets of lactate group maintained the Fe concentration on a more significant level $(p<0.01)$ (Fig. 7). The red blood count of these piglets was also temporarily higher than in the piglets of dextran group $(p<0.01)$ (Fig. 3).

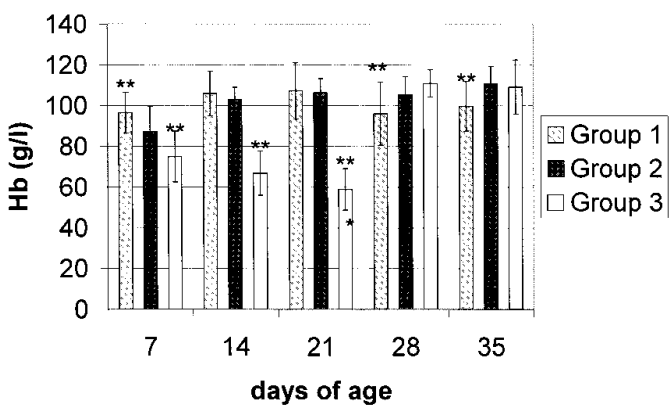

Fig. 1. Haemoglobin concentration $(\mathrm{Hb})$

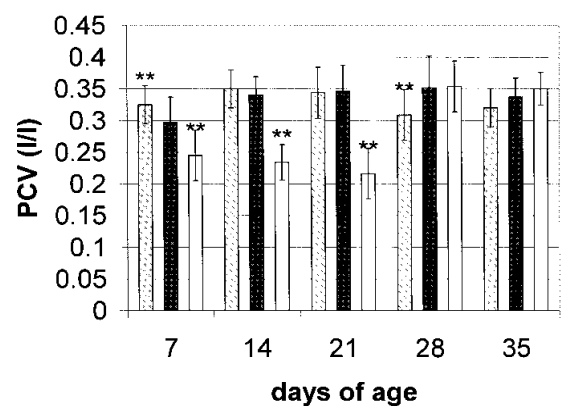

Fig. 2. Packed cell volume (PCV)

The above-mentioned differences disappeared in the next age group of three-week piglets and both experimental groups had almost identical values of all examined parameters (Figs. 1-8). 


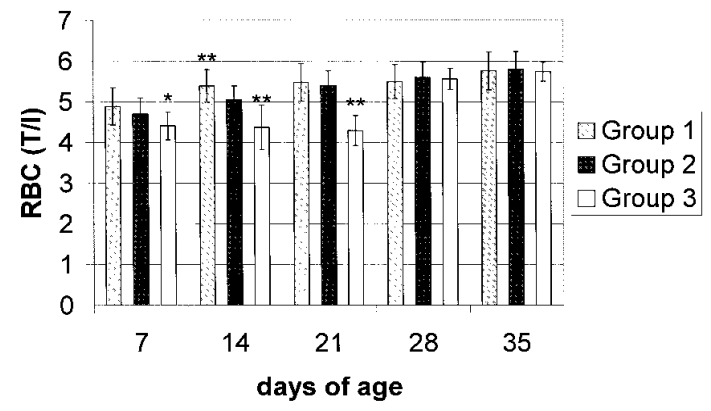

Fig. 3. Red blood cell count (RBC)

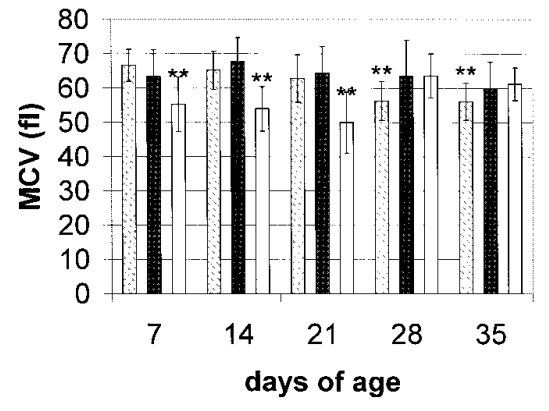

Fig. 4. Mean corpuscular volume (MCV)

A decrease in some haematological values was found in the lactate group on day 28 of life. E.g. Hb concentration in blood (Fig. 1), PCV (Fig. 2), MCV (Fig. 4) and MCH (Fig. 5) decreased significantly. As the dextran-Fe piglets did not show a similar decrease, there arose significant differences between the two groups. They were in favour of the dextran group in which these values were maintained on a significantly higher level including the plasma Fe concentration $(p<0.01)$ (Fig. 7).

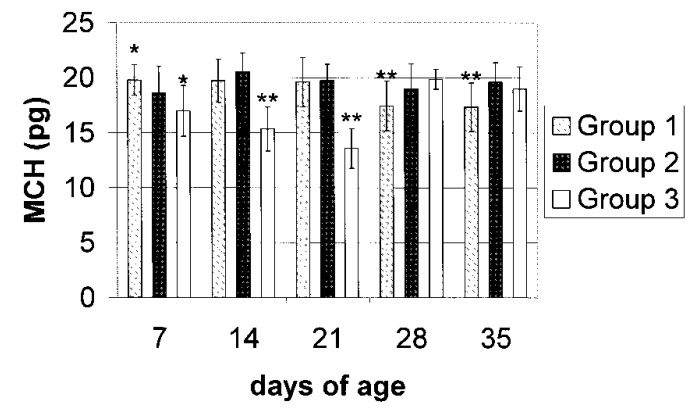

Fig. 5. Mean corpuscular haemoglobin (MCH)

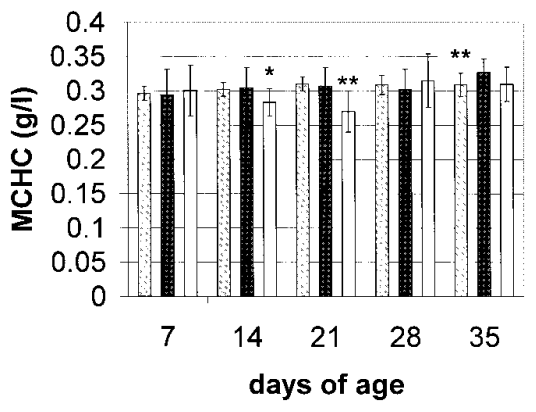

Fig. 6. Mean corpuscular haemoglobin concentration (MCHC)

In the last age category of 35-day piglets the above differences continued to exist although the differences in $\mathrm{Hb}$ concentration between the lactate and dextran group diminished and those in PCV and RBC disappeared completely (Figs. 1 and 2).

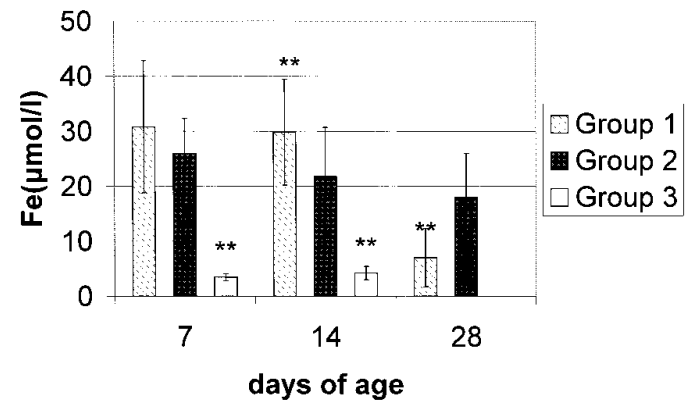

Fig. 7. Iron concentration in blood plasma $(\mathrm{Fe})$

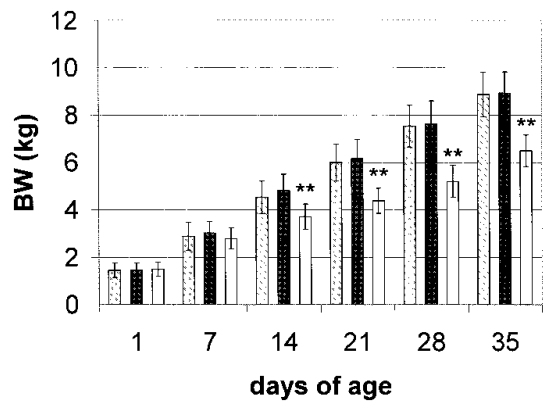

Fig. 8. Body weight (BW) 
In the group of control piglets the administration of $200 \mathrm{mg} F \mathrm{Fe}$ was followed by a rapid increase in all examined values to the level of experimental groups (Figs. 1-6). But the development of body weight of these piglets was considerably worse than in the two experimental groups. Both the lactate- and dextran-supplemented piglets had the identical growth rate for the whole experimental period (Fig. 8).

\section{Discussion}

The administration of lactate $\mathrm{Fe}^{2+}$ at a dose of $134 \mathrm{mg} /$ piglet on day 3 and 10 after birth positively influenced the development of most haematological indices of piglets in the first three weeks of their life. The found values were not only comparable with data determined in individuals with a single $i . m$. injection of $200 \mathrm{mg} \mathrm{Fe} e^{3+} /$ piglet but also at the end of the first week they exceeded them significantly in the main parameters. It agrees with the results of Framstad et al. (1997), who reported that orally administered $\mathrm{Fe}^{2+}$ was more readily utilisable for haemoglobin synthesis than $\mathrm{Fe}^{2+}$ given i.m. in the form of dextran. The utilisation of lactate Fe under experimental conditions was tested by Kotrbáček (2001). He reported a significant improvement of red blood cell indices after single oral dose of 90 $\mathrm{mg}$ Fe to one-day piglets. But he accentuated that a prerequisite of its utilisation was the good condition of digestive tract and timely stimulation of its resorptive abilities. According to Dividich et al. (1997) they are conditioned by timely and sufficient colostrum intake. Already within several hours after its ingestion the mucosal layer and particularly villi, which substantially increase the intestinal absorptive area, start growing.

Relatively high doses of lactate Fe were used in our experiments while the first administration of the paste was carried out on day 3 after birth. We decided on a later administration of the paste on the basis of findings of Süveges and Glávits (1976) and of Radostits et al. (1994), who pointed to a potential hazard of acute iron poisoning. The hazard is imminent especially in newborn piglets with insufficient reserves of vitamin $\mathrm{E}$. The concentration of this antioxidant increases rapidly with colostrum intake (Loudenslager et al. 1986; Kolb and Hoffmann 1989), i. e. the protection of piglets in the post-colostral period from possible oxidative effects of Fe ions is higher. The absence of any health complications after the administration of Fe paste and favourable development of haematological parameters in the first three weeks after birth documented unproblematic utilisation of lactate Fe supplement.

A sudden decrease in the $\mathrm{Hb}$ concentration between day 21 and 28 in the supplemented piglets was somewhat surprising. Even though the average $\mathrm{Hb}$ values did not decrease below the level of $80 \mathrm{~g} / \mathrm{l}$ that is considered as limiting from the aspect of anaemia development (Furugouri 1975; van Kempen 1987), the simultaneous significant decrease in other haematological parameters reflected a gradual depletion of available iron reserves. This conclusion was drawn from the low plasma concentration of Fe and from a decrease in $\mathrm{MCV}$, PCV and MCH. According to Dubanský et al. (1997) development of microcytic anaemia is one of the early symptoms of Fe deficiency in the organism. Even though these changes did not influence the growth rate of piglets, they indicated undoubtedly that the Fe reserves constituted by the administration of paste on day 10 after birth were no longer sufficiently high to cover its requirement fully between day 21 and 28 of life as it was in DeFe-treated individuals.

To explain this fact it is necessary to describe in greater detail the mechanism of $\mathrm{Fe}$ absorption from the intestine and its further possible metabolic transformations in the organism. Orally administered $\mathrm{Fe}^{2+}$ can be oxidised to $\mathrm{Fe}^{3+}$ while less readily utilisable ferritin is formed. It happens under an increased supply of Fe or under its lower transfer from the cells of intestinal mucosa to blood. Ferritin as a depot compound is accumulated in enterocytes and passes into the intestinal lumen through their desquamation. If $\mathrm{Fe}$ is not 
absorbed, it leaves the organism in excrements. An accompanying phenomenon is tough dark-coloured faeces of piglets. Under increased erythropoiesis $\mathrm{Fe}^{2+}$ without transformation to depot intestinal ferritin is transported into blood directly, and bound to transferrin it is carried to the bone marrow, liver, spleen and other organs (Pallister 1999; Andrew s and Smith 2000). It can readily be used for the synthesis of haemoglobin and myoglobin or stored. The above analysis shows that for more efficient utilisation of lactate Fe the second administration of paste should be postponed to the beginning of the third week of life. It is the time of intensive growth of piglets. Depot Fe is mostly utilised at that time because its intake with feed is not sufficient for the time being (Steinhard et al. 1984). The postponement of the second administration of paste to this period or an increase in the administration dose of Fe would undoubtedly be advisable from the aspect of physiological needs of piglets in the last week of their suckling life.

Other changes in the examined values were found out on day 35, i.e. at the end of the first week after piglet weaning. Even though the dextran piglets still had higher values of some parameters than the lactate group, the differences started diminishing. For example, Hb concentration increased to ca. $100 \mathrm{mg} / \mathrm{l}$ in the lactate group while RBC and PCV increased to the level measured in piglets with the $i . m$. administration of Fe. It was obviously the effect of dietary Fe that covered the Fe need of piglets due to the content of $248 \mathrm{Fe} / \mathrm{kg}$ feed and its regular intake. As expected, typical symptoms of anaemia occurred in the control group. It is interesting that they appeared at the end of the first week of life, becoming more severe in subsequent 2 weeks. It was also confirmed by the conclusions of S voboda and Drábek (2002) that piglets should be administered Fe before day 6 after their birth to prevent anaemia. Although all haematological values rapidly changed towards the physiological values after DeFe administration on day 21 , the somatic development of these piglets continued to lag behind the two experimental groups.

A conclusion can be drawn from the experimental results that the oral administration of lactate $\mathrm{Fe}^{2+}$ on day 3 and 10 after birth had positive effects on haematological values of piglets in the first three weeks of their life. In this supplemented group a decrease in most examined values was observed at the end of the fourth week; we believe that this decrease was connected with depletion of available iron reserves. Even though it did not influence the growth of suckling piglets and was partly compensated for at the end of the first week after weaning, it should be prevented. It is advisable to postpone the second administration of lactate Fe paste to the beginning of the third week of piglet life.

\section{Vliv perorální aplikace laktátu železa na vývoj hematologických ukazatelů selat v časném postnatálním období}

Cílem práce bylo zjistit účinek perorální aplikace laktázové pasty (LaFe) na postnatální vývoj hematologických parametrů selat. Prvá skupina, 39 selat, obdržela 3. den života 134 $\mathrm{mg} / \mathrm{kus} \mathrm{Fe}^{2+}$ formou LaFe. Stejná aplikace se této skupině opakovala u selat 10denních. Druhé (DeFe) skupině (30 selat), bylo aplikováno $200 \mathrm{mg} \mathrm{Fe} \mathrm{F}^{3+} / \mathrm{kus}$ i.m. ve formě dextranu železa. Skupina 20 selat sloužila jako kontrolní anemická skupina. Na konci prvního týdne života nejvyšší hodnoty $\mathrm{Hb}, \mathrm{PCV}$ a MCH byly zjištěny u laktátové skupiny $(p<0,01)$. Ve věku 14 dní byly v laktátové skupině zjištěny vyšší počty RBC a vyšší konemtrace plazmatického Fe. Dvacátý osmý den života byly nalezeny významné vyšší hodnoty většiny hematologických ukazatelů selat s i.m. aplikací dextranu železa $(p<0,01)$. Mezi oběma skupinami nebyly zjištěny rozdíly v intenzitě růstu. U kontrolní skupiny byla již v 7 dnech života anémie.

Aplikace laktátové Fe pasty selatům 3. a 10. den po narození pozitivně ovlivňovala jejich hematologické ukazatele v prvých třech týdnech života, ale ve 4. týdnu se projevily známky vyčerpání rezerv Fe. 


\section{Acknowledgements}

Supported by the project FRVŠ MŠMT No. 1492 / 2004.

\section{References}

ANDREWS, GA, SMITH, JE 2000: Iron metabolism. In: Feldman, B. F.,Zinkl, J. G., Jain, N. C. (Eds): Schalms Veterinary Hematology. $5^{\text {th }}$ Ed. Philadelphia, Lippincott Williams and Wilkins, pp. 129-134

AVRAM, N, MACONEI, N, ZABAVA, R, VOINEAG, V 1982: Adverse reactions in piglets injected with iron dextran for prevention of anaemia. Rev. Crest. Animalelor, 11: p. 45

CARLSSON, H, LINDVALL, S, THAFVELIN, B 1974: Properties of a complex of iron and a sorbitol-gluconic acid polymer for treatment of piglet anaemia. Acta Vet Scand 15: 100-110

DIETZFELBINGER, H 1987: Bioavailability of bi- and trivalent oral iron preparations. Investigations of iron absorption by postabsorption serum iron concentrations curves. Arzneimittelforschung 37: 107-112

DIVIDICH, J, TIVEY, D, BLUM, JW, STRULLU, F, LOUAT, C 1997: Effect of amount of ingested colostrum on the small intestine growth and lactase activity in the newborn pig. In: Digestive Physiology of Pigs. EAAP Publication No 88, St. Malo

DUBANSKÝ, V, ŽIŽLAVSKÝ, M, CHLOUPEK, J 1997: Disorders of cellular and humoral immunity of piglets as a result of inadequate Fe administration (Poruchy buněčné a humorální imunity selat v důsledku nesprávné aplikace Fe). Veterinářství 47: 413-417

FRAMSTAD, T, EGELI, AK, BLOM, AK, SJAASTAD, OV 1997: Effects of iron in strongly anaemic piglets. Book of abstracts of the annual meeting of the European Association for Animal Production, Vienna, Austria 3: p. 356

FURUGOURI, K 1975: Characteristic aspects of iron metabolism in piglets. Jap Agric Res Quart 9: 171

HEINRITZI, K, PLONAIT, H 1997: Blutkrankheiten. In Lehrbuch der Schweinekrankheiten, $2^{\text {nd }}$ ed., Ed. H. Plonait, K. Bickhardt, Parey Buchverlag Berlin, p. 190

HOLMGREN, N 1996: Polyarthritis in piglets caused by iron dextran. Bologna, Proc IPVS Congress, p. 306

KOLB, E, HOFFMANN, U 1989: Zur Frage der zweckmassigen Form der Anwendung von Fe-dextran, seiner Verwertung sowie des Mechanismus einer möglichen Schädigung der Ferkel. Mh Vet Med 44: 497-501

KOLB, E, HOFFMANN, U, NESTLER, K 1992: Untersuchungen über den Gehalt an Eisen, Kupfer und Zink in verschiedenen Geweben (Magen-Darm-Kanal, Lymphknoten, Muskulatur, Herz, Leber, Milz, Niere, Pankreas, Knochenmark) bei neugeborenen Ferkeln nach oraler und intramuskularer Verabreichung von Fe-Dextran. Mh Vet Med 47: 271-278

KOTRBÁČEK, V 2001: Effect of different formulae for oral and parenteral administration of iron on somatic growth and selected haematological indexes in piglets. Czech J Anim Sci 46: 49-54

LEHMANN, P 2001: Anaemia: A major medical problem in the world. Eur Clin Lab 20: 26-30

LOUDENSLAGER, MJ, KU, PK, WHETTER, PA, ULLREY, DE, WHITEHAIR, HD, STOWE, HD, MILLER,

ER 1986: Importance of diet of dam and colostrum to the biological antioxidant status and parenteral iron tolerance of pigs. J Anim Sci 63: 1905-1914

MORRIS, CJ, EARL, JR, TRENAM, CW, BLAKE, DR 1995: Reactive oxygen species and iron - a dangerous partnership in inflammation. Int J Biochem Cell Biol 27: 109-122

PALLISTER, CJ 1999: Haematology. 1st Ed. Oxford, Butterworth/Heinemann, p.262

RADOSTITS, OM et al. 1994: Iron deficiency. In: Veterinary Medicine (Ed. Radostits et al.) London, pp. $1398-1401$

SCHMITZ, H, MÜLLER, A 1971: Orale Eisensubstitution beim Saugferkel. Schweiz. Arch.Tierheilk. 115: 391-399

STEINHARDT, M, BÜNGER, U, FURCHT, G 1984: Zum Eisenbedarf des Schweines in den ersten 2 Lebensmonaten. Arch Exper Vet Med 38: 497-515

SVOBODA, M, DRÁBEK, J 2002: Effect of oral administration of $\mathrm{Fe}^{2+}$-fumarate on erythrocyte profile and growth rate of suckling piglets. Acta Vet Brno 71: 217-222

SÜVEGES, T, GLÁVITS, R 1976: Piglet losses due to parenteral application of iron-dextran preparatins. Acta Vet Acad Sci Hung 26: 257-262

VAN KEMPEN, GJM 1987: Avoid iron deficiency in piglets. Pigs 3: 10-11

YU IT, LIN J, WU, JF, YEN, HT, LEE, SL, YANG, TS 2002: Reevaluation of the necessity of iron injection to newborn piglets. Asian Austral J Anim 15: 79-83 